\title{
Faktor yang Berhubungan dengan Kejadian Computer Vision Syndrome pada Karyawan Bank
}

\section{Factors Associated with the Incidence of Computer Vision Syndrome in Bank Officers}

\author{
Nopriadi $^{1 *}$, Yuharika Pratiwi², Emy Leonita ${ }^{2}$, Erna Tresnanengsih ${ }^{2}$ \\ ${ }^{1}$ Fakultas Kesehatan Masyarakat Universitas Andalas \\ ${ }^{2}$ STIKes Hang Tuah Pekanbaru \\ (*nopriadi_dhs@yahoo.com)
}

\begin{abstract}
ABSTRAK
Computer Vision Syndrome (CVS) merupakan kumpulan gejala mata majemuk akibat menggunakan komputer. Berdasarkan survei awal diperoleh lebih dari tiga per empat karyawan Bank RK Pekanbaru yang kesehariannya bekerja menggunakan komputer mengalami CVS. Penelitian ini bertujuan mengetahui faktor yang berhubungan dengan CVS. Jenis penelitian ini adalah kuantitatif observasional dengan rancangan cross sectional dengan jumlah sampel sebanyak 117 responden. Analisis data yang digunakan adalah univariat, chi-square untuk analisis bivariat dan uji multiple logistic regression untuk analisis multivariat. Hasil penelitian menunjukkan bahwa karyawan Bank RK Pekanbaru yang mengalami keluhan CVS, yaitu berupa mata lelah dan tegang $54,3 \%$, nyeri pada leher $28,7 \%$, nyeri bahu $27,7 \%$, sakit kepala $25,5 \%$, pandangan kabur $20,2 \%$, melihat kembar $17 \%$, mata berair dan sulit fokus $14,9 \%$, nyeri punggung $11,7 \%$, mata perih, sakit iritasi sebesar 5,3\%. Berdasarkan hasil uji chi-square didapatkan variabel yang berhubungan dengan CVS adalah jarak penglihatan (nilai $\mathrm{p}=0,016$ ), posisi monitor (nilai $\mathrm{p}=0,011$ ), pencahayaan (nilai $\mathrm{p}=0,001$ ), masa kerja (nilai $\mathrm{p}=0,002$ ), lama bekerja (nilai $\mathrm{p}=0,000$ ). Variabel yang tidak berhubungan dengan CVS adalah umur (nilai $\mathrm{p}=0,561$ ). Variabel lama bekerja menggunakan komputer $\geq 4$ jam sehari, 9 kali lebih berisiko menyebabkan CVS pada karyawan Bank RK Pekanbaru. Penelitian menunjukkan bahwa faktor yang paling dominan berpengaruh terhadap CVS adalah lama bekerja, faktor lain yang berperan sebagai perancu yang mempengaruhi CVS yaitu posisi monitor, pencahayaan stasiun kerja, masa bekerja dengan komputer.
\end{abstract}

Kata kunci : Computer Vision Syndrome, lama bekerja

\begin{abstract}
Computer Vision Syndrome (CVS) is a collection of compound eye symp-toms due to using a computer. According to the initial survey, more than three quarter officers of Bank RK in Pekanbaru who daily work using computers experience CVS. This study aimed to determine factors associated with CVS. This type of study was quantitative observational with cross-sectional design with amount of sample 117 respondents. Data analysis used was univariate, chi-square used for bivariate analysis and multiple logistic regression used for multivariate analysis. Based on the chi-square analysis the results showed that Bank RK officers who experienced CVS complaints were in the forms of tired and tense eyes at $54,3 \%$, neck pain at 28,7\%, shoulder pain at $27,7 \%$, headache at $25,5 \%$, blurred vision at $20,2 \%$, seeing twins at $17 \%$, watery eyes and difficulty to focus at $14,9 \%$, back pain at $11,7 \%$, sore eyes, irritation pain at $5,3 \%$. Variables related to CVS were vision distance $(p=0.016)$, monitor position $(p=0.011)$, lighting $(p=0.001)$, working period $(p=0.002)$, the length of work $(p=0.000)$. Variables not related to CVS was age $(p=0.561)$. Variable of the length of work with computers $\geq 4$ hours a day was 9 times riskier of causing CVS in Bank RK officers. This study indicates that the most dominant factor influential to CVS is the length of work, while other factors that act as confounding that affect CVS are monitor position, the lighting of the work station, the period of working with computer.
\end{abstract}

Keywords : Computer Vision Syndrome, the length of work 


\section{PENDAHULUAN}

Kemajuan teknologi informasi telah berkembang lebih dari 20 tahun, salah satunya dengan ditemukannya komputer. ${ }^{1}$ Penggunaan komputer menjadi bagian yang tidak dapat dipisahkan di tempat kerja karena memudahkan pekerjaan dan memberikan hasil yang lebih cepat. ${ }^{2}$ Namun, komputer dapat menimbulkan dampak bagi kesehatan.

Occupational safety and health administration (OSHA) mendefinisikan computer vision sydrome (CVS) sebagai keluhan mata dan penglihatan kompleks yang dialami ketika menggunakan komputer. Menurut Asosiasi Optometrik Amerika, CVS merupakan masalah mata majemuk yang berkaitan dengan pekerjaan jarak dekat yang dialami seseorang ketika menggunakan komputer. Tidak ada yang dapat menjelaskan penyebab pasti terjadinya CVS dikarenakan banyak faktor yang berperan dalam kejadian CVS diantaranya faktor individual, faktor lingkungan dan faktor komputer. ${ }^{1,3,4}$

Seiring dengan meningkatnya penggunaan komputer maka jumlah penderita dengan keluhan penglihatan yang dikelompokkan bersama dalam istilah CVS juga semakin meningkat, seperti ketegangan dan kelelahan pada mata, sensasi terbakar, iritasi, kemerahan, pandangan kabur, mata kering, dan sebagainya. ${ }^{5}$ Gejala CVS dikelompokkan menjadi empat kelompok mayor, yaitu Astenopi (mata tegang, lelah, dan perih), berhubungan dengan permukaan bola mata (mata kering, berair, iritasi, masalah penggunaan kontak lens), penglihatan (penglihatan kabur, lambat dalam perubahan fokus, penglihatan ganda, presbiopi), ekstraokular (nyeri leher, nyeri punggung, dan nyeri bahu). ${ }^{6}$ Menurut Cole \& Collins ${ }^{7}$ bahwa gejala di atas merupakan kombinasi dari masalah penglihatan, buruknya kondisi kerja, dan kebiasaan yang salah.

Beberapa penelitian menyebutkan bahwa 90\% dari 70 juta pekerja di Amerika menggunakan komputer lebih dari 3 jam perhari. ${ }^{7-9}$ Rata-rata pekerja di Amerika menghabiskan waktu 7 jam per hari di kantor maupun di rumah menggunakan komputer. ${ }^{10}$ Jutaan kasus baru dapat terjadi setiap tahunnya. ${ }^{3,5}$ Keluhan CVS ditemukan di Malaysia sebesar $61,4 \%$ pekerja mengalami nyeri punggung bagian bawah nyeri bahu dan leher sedangkan ketegangan pada mata terbanyak sebesar $70,6 \%{ }^{1}$
Peneliti luar negeri dari berbagai bidang (seperti Asosiasi Optometrik Amerika, kedokteran okupasi, manajemen bisnis dan teknologi, dan sebagainya) telah banyak melakukan penelitian mengenai faktor yang berhubungan dengan kejadian CVS, tetapi sayangnya di Indonesia penelitian mengenai CVS masih belum banyak dilakukan padahal banyak pekerja perkantoran di Indonesia yang sehari-harinya menggunakan komputer terutama dunia perbankan. Pekerja di bank dalam kesehariannya tidak terlepas dari penggunaan komputer untuk menginput, menganalisis data nasabah berupa angka-angka, dan ini membutuhkan ketelitian dan konsentrasi tinggi (beban kerja yang tinggi).

Beberapa penelitian di Indonesia mengenai CVS, seperti dari penelitian Azkadina, ${ }^{11}$ menyatakan prevalensi penderita CVS sebesar 66,8\% pada responden Bank Jateng, RSI Sultan Agung dan RSUP dr. Kariadi. Anggraini, ${ }^{12}$ menyatakan $88,5 \%$ responden mengalami keluhan CVS pada operator komputer PT. Bank Kalbar yang terbanyak dialami adalah astenopia, nyeri pada leher/ bahu dan punggung serta mata kering sebesar 23,2\%. Penelitian yang dilakukan Kusumawaty, et al, ${ }^{13}$ di PT. Bank Negara Indonesia - Makassar, menyatakan bahwa astenopia menjadi lebih berat dengan semakin banyaknya keluhan subjektif yang dialami seperti penurunan visus, dan terjadi peningkatan risiko mata kering. Menurut Anggraini, ${ }^{12}$ semakin lama masa kerja seseorang semakin besar risiko mengalami CVS. Keluhan tersebut dapat menyebabkan menurunnya jam kerja dan mengurangi kenyamanan bekerja sehingga berdampak pada produktivitas kerja. Penurunan produktivitas kerja akibat CVS diperkirakan sebesar $40 \%{ }^{14}$

Tidak ada yang dapat menjelaskan penyebab pasti terjadinya CVS dikarenakan banyak faktor yang berperan dalam kejadian CVS, diantaranya faktor individual, lingkungan dan komputer. ${ }^{1}$ Berdasarkan prinsip kesehatan kerja di Indonesia, Depkes RI mengelompokkan faktor tersebut ke dalam prinsip K3 dasar meliputi faktor kapasitas kerja, beban kerja dan lingkungan kerja. Ketiga kelompok tersebut harus seimbang, masalah kesehatan kerja dapat timbul akibat ketidakseimbangan faktor tersebut. ${ }^{15}$

Berdasarkan informasi yang diperoleh dari karyawan Bank RK Pekanbaru, ada beberapa 
karyawan mengalami keluhan CVS terkait dalam pekerjaan mereka menggunakan komputer. Survei awal dilakukan dengan menggunakan kuesioner yang disebar di seluruh bagian/divisi dari 8 cabang Pusat Bank RK Pekanbaru (Pasar Pusat, A. Yani, Harapan Raya, Panam, Senapelan, Rumbai, Nangka, dan di jalan Riau, Pekanbaru), pada karyawan diperoleh lebih dari 75\% karyawan Bank RK Pekanbaru mengalami CVS setelah bekerja menggunakan komputer dengan variasi keluhan ringan seperti mata lelah, mata tegang, sakit kepala, dan sebagainya namun keluhan tersebut lebih sering diabaikan. Berdasarkan uraian tersebut, penelitian ini bertujuan mengkaji lebih dalam mengenai faktor yang berhubungan dengan CVS pada karyawan pengguna komputer di Bank RK Pekanbaru.

\section{BAHAN DAN METODE}

Penelitian ini bersifat kuantitatif analitik observasional dengan jenis desain studi cross sectional. Penentuan sampel dengan perhitungan rumus Kelsey. ${ }^{24}$ Pengambilan sampel dilakukan oleh peneliti sendiri, dengan cara memilih karyawan yang memenuhi kriteria inklusi sampai kriteria sampel minimal terpenuhi. Penyebaran kuesioner dilakukan pada 144 orang karyawan Bank RK Pekanbaru (total populasi), tetapi kuesioner yang diperoleh sebanyak 117 karyawan, 27 karyawan termasuk dalam kriteria eksklusi dikarenakan menolak mengisi kuesioner tanpa alasan, mengkonsumsi obat hipertensi, hamil, memakai lensa kontak, dan dinas luar. Teknik pengambilan sampel dilakukan dengan total sampling.

Pengambilan sampel dilakukan secara bertahap, pada bulan Agustus - September 2016. Pengumpulan data dengan menggunakan kuesioner yang telah diuji validitas dan reliabilitas nya. Setelah pengisian kuesioner, dilanjutkan dengan pengamatan ergonomi di stasiun kerja, dan pengukuran intensitas pencahayaan dengan menggunakan lux meter digital pada stasiun kerja. Pengolahan data menggunakan komputerisasi, dan analisis data dilakukan secara univariat, bivariat dengan uji chi-square dan multivariat dengan uji multiple logistic regression.

\section{HASIL}

Berdasarkan hasil kuesioner diketahui sebanyak 95 responden $(81,2 \%)$ mengalami CVS, dengan keluhan bervariasi, yaitu mengalami mata lelah dan tegang $54,3 \%$, nyeri pada leher $28,7 \%$, nyeri bahu $27,7 \%$, sakit kepala $25,5 \%$, pandangan kabur 20,2 \%, penglihatan kembar $17 \%$, mata berair dan sulit fokus $14,9 \%$, nyeri punggung $11,7 \%$, mata perih, sakit iritasi sebesar 5,3\%. Selain itu diperoleh sebanyak 22 responden $(18,8 \%)$ tidak mengalami CVS. Persentase responden yang mengalami CVS (+) dan CVS (-) (Tabel 1).

Berdasarkan hasil uji statistik chi-square didapatkan variabel jarak penglihatan dengan nilai p 0,016 $(<0,05)$, maka terdapat hubungan dengan kejadian CVS pada karyawan Bank RK (Tabel 2).

\section{Tabel 1. Tabel Distribusi Frekuensi}

\begin{tabular}{lll}
\hline \multicolumn{1}{c}{ Variabel } & $\mathbf{n}=\mathbf{1 1 7}$ & $\mathbf{\%}$ \\
\hline CSV & & \\
$\quad$ Penderita CSV & 95 & 81,8 \\
$\quad$ Bukan Penderita & 22 & 18,8 \\
Jarak Penglihatan & & \\
$\quad$ Berisiko & 59 & 50,4 \\
$\quad$ Tidak Berisiko & 58 & 49,6 \\
Posisi Monitor & & \\
$\quad$ Berisiko & 55 & 47 \\
$\quad$ Tidak Berisiko & 62 & 53 \\
Pencahayaan & & \\
$\quad$ Berisiko & 58 & 49,6 \\
$\quad$ Tidak Berisiko & 59 & 50,4 \\
Masa Kerja & & \\
$\quad$ Berisiko & 56 & 47,9 \\
$\quad$ Tidak Berisiko & 61 & 52,1 \\
Lama Bekerja & & \\
$\quad$ Berisiko & 56 & 47,9 \\
$\quad$ Tidak Berisiko & 61 & 52,1 \\
Umur & & \\
$\quad$ Berisiko & 52 & 44,4 \\
$\quad$ Tidak Berisiko & 65 & 55,6 \\
\hline
\end{tabular}

Nilai POR 3,365 (C.I.95\% OR=1,211-9,350), artinya karyawan dengan jarak penglihatan kurang dari $50 \mathrm{~cm}$ atau lebih dari $50 \mathrm{~cm}$ berisiko $3,3 \mathrm{kali}$ mengalami mengalami CVS dibandingkan dengan karyawan yang jarak penglihatan dari monitor 50 $\mathrm{cm}$.

Berdasarkan hasil uji statistik chi-square didapatkan variabel posisi monitor terhadap ketinggian horizontal mata dengan nilai $\mathrm{p}=0,011$, maka terdapat hubungan dengan kejadian CVS. Nilai POR=3,778 (C.I.95\%: OR = 1,289-11,073), artinya karyawan dengan posisi bagian atas monitor tidak sejajar (lebih tinggi atau lebih rendah) 
Tabel 2. Hubungan Variabel Independen dengan CVS

\begin{tabular}{|c|c|c|c|c|}
\hline \multirow{2}{*}{ Variabel } & \multicolumn{2}{|c|}{ CVS } & \multirow{2}{*}{ p } & \multirow{2}{*}{ POR $(95 \%$ CI) } \\
\hline & Ya & Tidak & & \\
\hline \multicolumn{5}{|l|}{ Jarak Penglihatan } \\
\hline Berisiko & 53 & 6 & 0,016 & 3,365 \\
\hline Tidak Berisiko & 42 & 16 & & $(1,211-9,350)$ \\
\hline \multicolumn{5}{|l|}{ Posisi Monitor } \\
\hline Berisiko & 50 & 5 & 0,011 & 3,778 \\
\hline Tidak Berisiko & 45 & 17 & & $(1,289-11,073)$ \\
\hline \multicolumn{5}{|l|}{ Pencahayaan } \\
\hline$<280 \operatorname{lux}$ & 54 & 4 & 0,001 & 5,927 \\
\hline $280-300$ & 41 & 18 & & $(1,864-18,849)$ \\
\hline \multicolumn{5}{|l|}{ Masa Kerja } \\
\hline 5 tahun & 52 & 4 & 0,002 & 5,442 \\
\hline$<5$ tahun & 43 & 18 & & $(1,712-17,295)$ \\
\hline \multicolumn{5}{|l|}{ Lama Bekerja } \\
\hline 4 jam/hari & 54 & 2 & 0,000 & 13,171 \\
\hline$<4$ jam/hari & 41 & 20 & & $(2,912-59,572)$ \\
\hline \multicolumn{5}{|l|}{ Umur } \\
\hline 40 tahun & 41 & 11 & 0,561 & 0,759 \\
\hline$<40$ tahun & 54 & 11 & & $(0,300-1,923)$ \\
\hline \multicolumn{5}{|l|}{ Jenis Kelamin } \\
\hline Perempuan & 55 & 14 & 0,622 & 0,786 \\
\hline Laki-Laki & 40 & 8 & & $(0,301-2,051)$ \\
\hline
\end{tabular}

terhadap ketinggian horizontal mata berisiko 3,7 kali mengalami CVS dibandingkan pada karyawan dengan posisi bagian atas monitor sejajar terhadap ketinggian horizontal mata.

Berdasarkan hasil uji statistik chi-square didapatkan variabel pencahayaan dengan nilai $\mathrm{p}=0,001$, maka terdapat hubungan dengan kejadian CVS pada karyawan Bank RK. Nilai POR $=5,927$ (C.I.95\%: OR = 1,864-18,849), artinya karyawan yang bekerja dengan pencahayaan di tempat stasiun kerja kecil dari 280 luxmeter berisiko 5,9 kali mengalami CVS dibandingkan dengan karyawan yang bekerja dengan pencahayaan di tempat stasiun kerja 280-300 lux meter.

Berdasarkan hasil uji statistik chi-square didapatkan variabel masa kerja dengan nilai $\mathrm{p}=0,002$, maka terdapat hubungan dengan kejadian CVS pada karyawan Bank RK. Nilai POR $5,442(\mathrm{CI} 95 \%=1,712-17,295)$, artinya karyawan yang bekerja dengan masa kerja 5 tahun menggunakan komputer berisiko 5,442 kali mengalami CVS dibandingkan dengan masa kerja kurang dari 5 tahun.

Berdasarkan hasil uji statistik chi-square didapatkan variabel lama bekerja dengan nilai $p$
0,000, maka terdapat hubungan dengan kejadian CVS pada karyawan Bank RK. Nilai POR $=13,171$ $(\mathrm{CI} 95 \%=2,912-59,572)$, artinya karyawan yang bekerja 4 jam/hari menggunakan komputer berisiko 13 kali mengalami CVS dibandingkan karyawan yang lama bekerja kurang dari 4 jam/ hari menggunakan komputer.

Berdasarkan hasil uji statistik chi-square didapatkan variabel umur dengan nilai $\mathrm{p}=0,561$, maka tidak terdapat hubungan dengan kejadian CVS pada karyawan Bank RK. Begitu juga dengan hasil uji statistik variabel jenis kelamin dengan nilai $\mathrm{p}=0,622$, maka tidak terdapat hubungan dengan kejadian CVS pada karyawan Bank RK Pekanbaru.

Setelah dilakukan uji multiple logistic regression pada analisis multivariat, maka diketahui variabel yang paling berpengaruh dengan CVS, yaitu variabel lama bekerja di depan komputer. Karyawan yang bekerja di depan komputer 4 jam berisiko 9 kali mengalami CVS dibandingkan karyawan yang bekerja kurang dari 4 jam. Variabel perancu adalah jarak penglihatan, posisi monitor, masa kerja, pencahayaan di tempat stasiun kerja. Model multivariat yang terbentuk sudah fit 
atau layak digunakan kemaknaan model signifikan (nilai p Omnimbus Test $<0,000$ ). Negelkerke $\mathrm{R}$ Square 0,263 artinya 5 variabel yang diteliti tersebut (jarak penglihatan, posisi monitor, masa kerja, pencahayaan dan lama bekerja di depan komputer) dapat menjelaskan CVS sebesar $26,3 \%$, sisanya kemungkinan disebabkan oleh variabel lain (faktor genetik, autoimun, status gizi, suhu, kelembaban, dan sebagainya) yang tidak diteliti.

\section{PEMBAHASAN}

Jarak penglihatan pada komputer berhubungan dengan kejadian CVS. Terdapat hubungan jarak melihat monitor komputer dengan kejadian CVS pada karyawan Bank RK Pekanbaru. Hasil penelitian ini sesuai dengan penelitian yang dilakukan oleh Shantakumari et al, ${ }^{16}$ pada pelajar di Ajman, Arab Saudi, diperoleh bahwa pelajar yang melihat layar komputer dengan jarak $<50 \mathrm{~cm}$ (tanpa menggunakan anti silau dan bekerja dalam waktu yang lama dengan komputer), keluhan menjadi berkurang jika jarak penglihatannya ditingkatkan $50 \mathrm{~cm}$.

OSHA menjelaskan bahwa jarak yang dianjurkan untuk melihat monitor komputer berkisar 18-24 inchi $(45,72-60,96 \mathrm{~cm})$, rata-rata berjarak $50,80 \mathrm{~cm} .{ }^{17}$ Shantakumari, ${ }^{16}$ menyatakan bahwa jarak ideal untuk melihat komputer yaitu pada 50$70 \mathrm{~cm}$. Kanitkar et al, ${ }^{18}$ menjelaskan bahwa pada jarak 50-70 $\mathrm{cm}$ mata berada dalam kondisi fisiologis, yang mana mata akan istirahat dari akomodasi.

Jarak penglihatan pada komputer berhubungan dengan kejadian CVS. Jarak yang terlalu jauh dari monitor $(>50 \mathrm{~cm})$ ditambah durasi kerja yang lama dapat menyebabkan mata lelah. Pengaturan jarak penglihatan sepanjang lengan sebaiknya disosialisasikan (umumnya $50 \mathrm{~cm}$ ). Sesama karyawan dapat saling mengingatkan, pimpinan dapat menegur karyawan yang jarak penglihatannya kurang dari $50 \mathrm{~cm}$, memasang poster tentang ergonomi komputer di dinding tiap bagian agar setiap saat karyawan ingat dan merubah posisinya. Pada karyawan yang menggunakan kacamata bifokal, posisikan kacamata senyaman mungkin dengan kemampuan penglihatan sehingga tidak menyebabkan beban pada mata, leher, bahu dan punggung dalam penyesuaiannya.

Terdapat hubungan posisi bagian atas mo- nitor terhadap ketinggian horizontal mata dengan kejadian CVS pada karyawan Bank RK Pekanbaru. Hasil penelitian ini sesuai dengan penelitian yang dilakukan oleh Reddy et $\mathrm{al},{ }^{17}$ menemukan ada hubungan antara posisi bagian atas monitor komputer terhadap mata dengan kejadian CVS pada mahasiswa di Universitas Malaysia dengan nilai $\mathrm{p}=0,001$. Gejala sakit kepala, mata tegang, mata kering, sensasi terbakar, sensasi berpasir, berair, bahu kaku, nyeri punggung, dan kelelahan dilaporkan meningkat seiring lamanya penggunaan komputer sehari-hari. Menghabiskan waktu yang lama dengan layar komputer tanpa berhenti sejenak dapat menimbulkan masalah perubahan fokus pada layar, dokumen dan keyboard. ${ }^{5,7}$

Posisi bagian atas monitor lebih tinggi atau lebih rendah dari ketinggian horizontal mata menyebabkan lebarnya pembukaan kelopak mata sehingga mata menjadi kering, dan juga terjadi penyesuaian kepala terhadap monitor (postur janggal: membungkuk/mendongak) menyebabkan terjadinya GOTRAK (gangguan otot tulang rangka akibat kerja). Posisi atas monitor dapat diatur naikturun dan ditempatkan sejajar sesuai dengan posisi mata. Sudut penglihatan mata terhadap komputer dianjurkan sebesar 100-200, sehingga karyawan tidak perlu terlalu menunduk jika posisinya lebih rendah atau terlalu mendongak ke atas jika posisinya terlalu tinggi karena dapat menyebabkan nyeri pada leher, bahu dan punggung. Peregangan pada leher, bahu dan punggung setiap 1 jam dapat dilakukan untuk menghindari GOTRAK. Menggunakan dokumen holder yang sejajar dengan pandangan dan komputer dengan jarak yang tidak terlalu jauh dari komputer ketika menginput data.

Penempatan monitor di meja kerja disesuaikan dengan posisi tubuh karyawan. Ketinggian meja dari lantai umumnya 25-34 inci, dan kursi juga harus disesuaikan dengan postur tubuh (antropometri) karyawan dan ketinggian meja sehingga kursi kerja harus ergonomis (sandaran punggung menyesuaikan lekukan tulang belakang, terdapat penyangga tangan, dan kursi dapat diatur ketinggiannya sedemikian rupa).

Terdapat hubungan pencahayaan yang kurang di stasiun kerja $(<280$ lux $)$ dengan kejadian CVS pada karyawan Bank RK Pekanbaru. Hasil penelitian ini sesuai dengan penelitian yang dilakukan oleh Shantakumari, ${ }^{16}$ bahwa penggu- 
naan komputer dalam ruangan yang sangat terang atau pada ruangan yang gelap dapat menyebabkan gangguan penglihatan. Ruangan yang terlalu terang menyebabkan sakit kepala dan ruangan yang terlalu gelap dapat menyebabkan mata kering. Pencahayaan komputer dan kontrasnya harus seimbang dengan pencahayaan ruangan.

Pencahayaan yang baik adalah pencahayaan yang memungkinkan seorang tenaga kerja melihat pekerjaannya dengan teliti, cepat dan tanpa upaya yang tidak perlu, serta membantu menciptakan lingkungan kerja yang nyaman. Pencahayaan harus cukup bagi pengguna komputer untuk melihat teks pada layar komputer, tidak terlalu terang yang dapat menyebabkan silau atau ketidaknyamanan pada mata. Kesilauan tergantung pada intensitas, ukuran, sudut, luminasi dan dekatnya sumber ke pandangan. Silau dapat bersumber dari cahaya langsung dalam lapang pandang (seperti jendela) atau cahaya pantulan dari keyboard atau yang berasal dari pantulan cahaya difus yang dapat mengurangi kontras. Silau dapat menyebabkan ketidaknyamanan dan berkurangnya kemampuan melihat (OSHA) ${ }^{17}$ Kondisi pencahayaan yang buruk di sekitar area komputer dapat berdampak buruk pada mata pengguna komputer. Kebanyakan kondisi pencahayaan di tempat kerja sebesar 50100 foot-candles. Pencahayaan yang tinggi dapat menyamarkan gambar di monitor.

Posisi karyawan dari samping yang terpapar langsung cahaya silau berasal dari jendela dapat dikurangi dengan memberikan tirai jendela. Sebaiknya posisi karyawan yang menggunakan komputer tidak menyamping dari jendela ataupun menghadap jendela, tetapi dianjurkan posisi karyawan membelakangi jendela (komputer menghadap jendela) sehingga mencegah kesilauan. Posisikan monitor komputer dengan sudut yang sesuai untuk menghindari silau yang berasal dari pantulan cahaya lampu di atas kepala. Monitor yang penuh debu dibersihkan karena berpengaruh terhadap pencahayaan. Atur kontras dan kecerahan monitor dengan baik, dianjurkan tulisan hitam dan latar belakang putih. Namun untuk komputer dengan kontras sebaliknya sebaiknya gunakan screen filter untuk menghindari silau yang tidak diinginkan. Karyawan yang beban kerjanya tinggi dapat dianjurkan untuk menggunakan kacamata anti silau dan sekaligus bersifat anti radiasi. Warna din- ding, lantai, plafon dan stasiun kerja tidak terlalu kontras/mencolok sehingga tidak menimbulkan silau. Meja kerja jangan yang dapat memantulkan cahaya, gunakan meja dengan warna gelap, dengan pinggiran meja yang tumpul tidak menyakitkan tangan pekerja ketika menyentuh pinggirnya), untuk menghindari GOTRAK. Jika kaki karyawan pendek dapat diberikan sandaran kaki

Terdapat hubungan masa kerja menggunakan komputer dengan kejadian CVS pada karyawan Bank RK Pekanbaru. Hasil penelitian ini sesuai dengan penelitian yang dilakukan oleh Anggraini, ${ }^{12}$ menemukan ada hubungan antara masa kerja karyawan PT. Bank Kalbar dengan kejadian CVS ( $p=0,008)$, membagi masa kerja menjadi dua kategori, sebesar $73,1 \%$ responden telah bekerja 4 tahun dan sebesar $26,9 \%$ responden bekerja $<4$ tahun. Utami, ${ }^{19}$ melakukan penelitian pada pekerja Harian Sumeks Grup Palembang, diperoleh sebesar 55\% pekerja yang sudah bekerja lebih dari 4 tahun, sehingga pekerja ini lebih besar kemungkinannya terpapar faktor risiko.

Reddy et al, mengutip dari Bergqvist dan Knave; Sanchez-Roman et al; Shima et al, yang mengemukakan bahwa masa kerja dengan komputer berhubungan langsung dengan gejala pada mata, panjangnya durasi cenderung menimbulkan keluhan menetap bahkan setelah selesai bekerja. ${ }^{7}$ Masa kerja menggunakan komputer berhubungan dengan lamanya durasi kerja, dapat berefek langsung pada mata, sehingga keluhan yang muncul ini lebih sering diabaikan dan akhirnya menetap bahkan setelah selesai bekerja. Penyuluhan mengenai efek komputer terhadap mata, bagaimana mengatasi dan kemana merujuk sebaiknya disosialisasikan agar keluhan yang timbul tersebut tidak semakin parah yang dapat menurunkan produktivitas kerja dan kerugian perusahaan. Karyawan yang telah bertahun-tahun bekerja menggunakan komputer dan juga kacamata sebaiknya dianjurkan untuk cek tajam penglihatan (visus) setiap tahun.

Karyawan yang mengalami CVS ketika bekerja lama (4 jam) di depan komputer, akan diperparah dengan pencahayaan yang buruk $(<280$ lux meter). Permenkes RI Nomor 48 Tahun 2016 Tentang Standar Keselamatan dan Kesehatan Kerja Perkantoran menganjurkan pencahayaan ruangan 300 lux meter. Pencahayaan ruangan kantor Bank RK Pekanbaru yang kurang memadai se- 
baiknya ditingkatkan menjadi 280-300 lux meter. Lampu yang kurang terang dapat ditambahkan di beberapa lokasi di atas kepala karyawan yang sebaran cahayanya merata, atau dapat juga ditambahkan lampu dinding. Pencahayaan tidak boleh menyebabkan silau atau memantulkan cahaya pada stasiun kerja.

Terdapat hubungan lama bekerja di depan komputer dengan kejadian CVS pada karyawan Bank RK Pekanbaru. Penelitian ini sejalan dengan penelitian Wimalasundera, ${ }^{5}$ dan Reddy et al, ${ }^{7}$ menjelaskan menghabiskan waktu yang lama dengan layar komputer tanpa berhenti sejenak dapat menimbulkan masalah perubahan fokus pada layar, dokumen dan keyboard. Rahman dan Sanip, ${ }^{20}$ dalam penelitiannya menyimpulkan bahwa istirahat sekurangnya 10 menit setelah 1 jam menggunakan komputer mengurangi keluhan mata tegang. Seseorang yang bekerja dengan menggunakan komputer $>7$ jam per hari cenderung mengalami CVS. OSHA menjelaskan durasi istirahat ketika menggunakan komputer dilakukan setiap 20 menit, melihat sesuatu dari kejauhan berjarak 20 feet (6 meter) selama 20 detik. ${ }^{17}$ Hal ini dapat mengurangi ketegangan pada mata dan merileksasi otot siliaris.

Hasil penelitian ini sesuai dengan penelitian yang dilakukan oleh Reddy et al mengutip dari penelitian Acousta et al; Nakazawa et al menyebutkan bahwa gejala sakit kepala, mata tegang, mata kering, sensasi terbakar, sensasi berpasir, berair, bahu kaku, nyeri punggung, dan kelelahan dilaporkan meningkat seiring lamanya penggunaan komputer sehari-hari. ${ }^{7}$ Ellahi et al, ${ }^{21}$ dalam penelitiannya menemukan hubungan penggunaan komputer yang lama ( $>4$ jam per hari) dapat menimbulkan kejadian CVS, stress, kelainan otot tulang dan rangka serta carpal tunnel syndrome.

Lama masa bekerja di depan komputer 4 jam pada karyawan pada karyawan Bank RK Pekanbaru berpengaruh 13 kali menimbulkan CVS dibandingkan dengan karyawan yang lama masa bekerja di depan komputer kurang dari 4 jam. Kebanyakan karyawan hanya beristirahat setelah 4 jam bekerja yaitu ketika jam istirahat. NIOSH dan AOA merekomendasikan rule of 20-20-20 untuk mencegah keluhan CVS Artinya karyawan yang menggunakan komputer dianjurkan untuk istirahat selama 20 detik setelah 20 menit menggunakan komputer (istirahat tanpa meninggalkan stasiun kerja, tetap melakukan pekerjaan lain selain menggunakan komputer), dan memandang objek yang berada pada jarak 20 kaki ( \pm 6 meter) ini bertujuan untuk mengurangi ketegangan pada otot yang menggerakkan bola mata (kelelahan otot terjadi setelah 15-20 menit bekerja tanpa istirahat) dan dengan melihat jarak \pm 6 meter diharapkan mata akan relaksasi. Rule of 20-20-20 ini dapat dijalankan dengan cara sosialisasi melalui penyuluhan, saling mengingatkan antar karyawan, dan memasang poster di dinding atau di meja kerja.

Meletakkan tumbuhan hijau di sudut ruangan atau aquarium mini memberikan kesegaran mata memandang. Untuk menghindari GOTRAK dapat dilakukan peregangan di stasiun kerja setiap 2 jam dan mengganti posisi yang nyaman. Selain itu, ketika bekerja dengan beban kerja yang tinggi dalam durasi kerja yang lama (misalnya 4 jam) dimana mata akan berkurang kedipannya dianjurkan menggunakan tetes mata untuk menghindari mata kering, karyawan diingatkan sesering mungkin untuk berkedip minimal 2 kali dalam 1 jam. Karyawan dengan beban kerja yang tinggi dan bekerja lama di depan komputer sebaiknya tidak menggunakan lensa kontak, gunakan kacamata koreksi yang sesuai. Jika ditemukan indikasi mata kering seperti mata terasa nyeri dan perih, teriritasi, terkadang mengalami hiperlakrimasi, secepatnya diperiksa ke dokter untuk penatalaksanaan lebih lanjut.

Hasil penelitian ini tidak ada hubungannya antara umur dengan CVS. Secara fisiologis, kondisi fisik orang yang berusia kurang dari 40 tahun lebih baik dibandingkan karyawan berusia 40 tahun, kondisi tersebut belum terjadi penurunan fungsi sel secara bermakna. Namun, pada kondisi tertentu karyawan yang berusia kurang dari 40 tahun dengan perokok berat, dapat mengalami proses degeneratif dini dikarenakan peningkatan radikal bebas di dalam tubuh dan berefek ke lensa. Selain itu, motivasi tinggi dalam bekerja disertai dengan tuntutan kebutuhan hidup yang lebih besar untuk peningkatan taraf hidup lebih baik, membuat karyawan yang berusia kurang dari 40 tahun termotivasi memperoleh bonus yang lebih besar jika produktivitas kerjanya meningkat dengan evaluasi terhadap pemenuhan target program kerja. Hal lain selain yang disebutkan di atas, diduga ada kaitannya dengan faktor lain yang tidak diteli- 
ti mempengaruhi umur seperti status gizi, genetik, suhu, dan lain-lain.

Chader dan Taylor, ${ }^{22}$ menyebutkan bahwa penyakit mata yang berhubungan dengan penuaan dapat berupa penyakit mata akibat komplikasi diabetes mellitus, mata kering, katarak, glukoma dan degenerasi makula. Sehubungan dengan mata kering, semakin bertambahnya umur seseorang kemampuan produksi air mata akan semakin berkurang akibat disfungsi kelenjar meibom menimbulkan ketidaknyamanan dan nyeri pada mata. Hal tersebut dapat memperberat kejadian CVS.

Penelitian ini tidak ada hubungan jenis kelamin wanita dengan kejadian CVS pada karyawan Bank RK Pekanbaru. Menurut Rozanova et al, ${ }^{23}$ dan Wimalasundera, ${ }^{5}$ banyak penelitian yang menjelaskan bahwa prevalensi mata kering pada wanita lebih tinggi dibandingkan pria. Wanita mengalami menopause yang dapat menyebabkan penurunan hormon estrogen dan mengakibatkan perubahan suasana hormonal setempat pada kelenjar lakrimal. Hal ini menurunkan produksi air mata dan berkontribusi terhadap mata kering pada wanita.

Bali et $a l,{ }^{6}$ mendukung pernyataan bahwa wanita lebih sering mengalami keluhan mata kering jika dibandingkan dengan pria. Demikian halnya dengan penelitian yang dilakukan oleh Rahman dan Sanip, ${ }^{20}$ mendukung pernyataan Rozanova et al,,$^{23}$ Wimalasundera, ${ }^{5}$; Azkadina, ${ }^{11}$ hasil penelitiannya menjelaskan bahwa wanita lebih banyak mengalami CVS dibandingkan dengan pria. Tidak sesuai dengan penelitian tersebut, hal ini terjadi karena beban kerja pria lebih besar daripada wanita dalam hal penambahan kerja di luar jam kerja, tidak seperti wanita yang mendapat perlindungan dalam Undang-Undang No 13 tahun 2003 mengenai jam lembur dibatasi sampai jam 23.00 WIB. Di Bank RK Pekanbaru, sebagian besar pria lebih sering lembur dibandingkan wanita terutama jika ada masalah selisih antara kas dan pembukuan, tutup buku akhir bulan dan beban kerja akan lebih meningkat pada saat tutup buku akhir tahun. Mengenai pembatasan jam kerja ini sesuai dengan data ILO Geneva tahun 2007, bahwa proporsi pekerja dengan jam kerja lebih pendek di Indonesia untuk wanita sebesar $25,9 \%$ dibandingkan pria $12,8 \%$ untuk karyawan yang digaji, dan untuk tenaga kerja yang mandiri proporsi pekerja dengan jam kerja lebih pendek lebih besar dari yang digaji yaitu $36,1 \%$ dan pria $21 \%$.

\section{KESIMPULAN DAN SARAN}

Proporsi karyawan RK Pekanbaru yang mengalami CVS $(81,2 \%)$ lebih besar daripada proporsi karyawan yang tidak mengalami CVS $(18,8 \%)$. Terdapat hubungan antara variabel independen (lama bekerja, posisi monitor, pencahayaan, masa kerja, dan lama kerja di depan komputer) dengan kejadian CVS pada karyawan Bank RK Pekanbaru. Variabel umur dan jenis kelamin tidak berhubungan dengan kejadian CVS. Variabel yang paling dominan berpengaruh terhadap CVS, yaitu variabel lama bekerja di depan komputer. Karyawan yang bekerja di depan komputer 4 jam berisiko 9 kali mengalami CVS dibandingkan karyawan yang bekerja kurang dari 4 jam. Variabel perancu adalah jarak penglihatan, posisi monitor, masa kerja, pencahayaan di tempat stasiun kerja. Disarankan kepada pihak manajemen Bank RK Pekanbaru untuk lebih memperhatikan aspek keselamatan dan kesehatan kerja di perkantoran yaitu mengatur stasiun kerja yang ergonomis, mensosialisasikan risiko dan upaya pencegahan gangguan kesehatan bagi karyawan bank salah satunya CVS dengan memasang poster di dinding dan mengatur program time warning yang diinstal pada komputer. Kepada karyawan agar melakukan metode 20-20-20 setiap jam, artinya setiap 20 menit, melihat sesuatu dari kejauhan berjarak 20 feet atau 6 meter selama 20 detik, melakukan peregangan, dan pengaturan pencahayaan dan ergonomic stasiun kerja sesuai standar.

\section{DAFTAR PUSTAKA}

1. Loh, K.Y., Reddy, S.C., Understanding and Preventing Computer Vision Syndrome. Malaysian Family Physician. 2008;3(3). ISSN : 1985-207X.

2. Khalaj, Mohammad, et al. Computer Vision Syndrome in Eleven to Eighteen Year-Old Students in Qazvin. Biotech Health Sci. $2015 \mathrm{Au}-$ gust; 2(3):e28234. DOI:10.17795/bhs-28234.

3. Affandi, Edi, S. Sindrom Penglihatan Komputer (Computer Vision Syndrome). Majalah Kedokteran Indonesia. 2005;55(3).

4. Rosenfield, Mark. Review Computer Vision Syndrome : a Review of Ocular Caus- 
es and Potential Treatments, Ophthalmic \& Physiological Optics. 2011;31:502-515. ISSN 0275 -5408. DOI : 10.1111/j.14751313.2011.00834. (http://onlinelibrary. wiley. com/doi/10.1111/j.1475-313.2011.00834.x/ epdf diakses pada tanggal 3 April 2016).

5. Wimalasundera, Saman. Computer Vision Syndrome. Galle Medical Journal. 2006;11(1).

6. Bali, Jatinder, Navin, Neeraj, Thakur, Bali, R. Computer Vision Syndrome : A Review : Journal of Clinical Ophthalmology and Research. 2007; 2(1).

7. Reddy, et al. Computer Vision Syndrome: a Study of Knowledge and Practices in University Students. Nepal J Ophthalmol. 2013;5(10):161-168.

8. Rom, William.N.. Environmental and Occupational Medicine. Dalam Goldsmith et al, Occupational Eye Disorder. Philadepia: Lippincott William and Wilkins. 2007;702-703.

9. Bansal, Y., Moudgil, Tania. Computer Vision Syndrome.International Journal of Innovative Research \& Development ISSN 22778-0211 (online). (http://www.ijird.com diakses pada tanggal 3 April 2016).

10. AOA. The Effects of Computer Use on Eye Health and Vision. 2015 (http://www.aoa.org diakses pada tanggal 3 April 2016).

11. Azkadina, Amira. Hubungan antara Faktor Risiko Individual dan Komputer terhadap Kejadian Computer Vision Syndrome. Dipublikasikan oleh Fakultas Kedokteran Universitas Diponegoro, 2012.

12. Anggraini. Faktor yang Berhubungan dengan Terjadinya Keluhan Computer Vision Syndrome (CVS) pada Operator Komputer PT Bank KalBar. Dipublikasikan oleh Fakultas Kedokteran Universitas Lampung, 2013.

13. Kusumawaty, S., Syawal, Siti R., Sirajuddin, Junaedi. Computer Vision Syndrome Pada Pegawai Pengguna Komputer di PT. Bank Negara Indonesia (Persero) TBK Makassar. Dipublikasikan oleh Fakultas, 2012.

14. Charpe, N.A., Kaushik, Vandana. Computer Vision Syndrome (CVS): Recognition and Control in Software Professionals. Kamia-Raj. J Hum Ecol. 2009;28(1):67-69.

15. Keputusan Menteri Kesehatan No. 261/MENKES/SK/II/1998. Persyaratan Kesehatan
Lingkungan Kerja. Depkes RI; 1998.

16. Shantakumari, Eldeeb, Sreedharan, Gopal. Computer Use and Vision-Related Problems Among University Students In Ajman, United Arab Emirate, Ann Med Health Sci Res. 2014;4(2):258-263. DOI:10.4103/21419248.129058.

17. Occupational Safety and Health Administration. Working Safely with Video Display Terminal. 1997.

18. Kanitkar, Kunal., Carlson, Alan., Richard. Occular Problem Associated With Computer Use, 2005.

19. Utami, Wiga. Virgian. Analisis Faktor yang Berhubungan Dengan Kejadian Computer Vision Synrome (CVS) pada Karyawan Harian Sumatera Ekspre Group Palembang Tahun 2014. Dipublikasikan oleh Fakultas Kesehatan Masyarakat Universitas Sriwijaya; 2014.

20. Rahman, Zairina.A., Sanip, Suhaila. Compute User : Demographic and Computer Related Factors that Predispose User to Get Computer Vision Syndrome. International Journal of Business, Humanities and Technology. 2011;1(2).

21. Ellahi, Abida., Khalil, M.Shahid., Akram, Fouzia. Computer Users at Risk : Helath Disorders Associated wih Prolonged Computer Use. E3 Journal of Business Management and Economics. 2011;2(4):171-182.

22. Chader, Gerald J.,Taylor, Allen. Preface : The Aging Eye : Normal Changes, Age-Related Diseases, and Sight-Saving Approaches. Investigative Ophthalmology \& Visual Science 2013;54: ORSF1- ORSF4. DOI: 10.1167/ iovs.13-12993, ISSN : 1552-5783.

23. Rozanova, Elena., Heilig, Peter., Godnic-cvar,Jasminka.. The Eye - A Neglected Organ in Environmental and Occupational Medicine: an Overview of Known Environmental and Occupational Non-Traumatic Effects on The Eyes. Arh Hig Rada Toksikol 2009;60: 205-215. DOI :10.2478/10004-1254-60-20091869.

24. Rahman, Topan Aditya. Analisis Statistik Penelitian Kesehatan (Prosedur Pemilihan Uji Hipotesis Penelitian Kesehatan). Bogor : IN Media Anggota IKAPI; 2015 